\title{
A Comparison between Islamic Banking and Conventional Banking Sector in Pakistan
}

\author{
Abdul Hafeez Quresh*, Zile Hussain, Kashif Ur Rehman \\ Iqra University, Islamabad Campus, Pakistan \\ *abdulhafeezqurashi@yahoo.com
}

\begin{abstract}
The Islamic banking system is attaining enormous development. Several modern international conventional banks were also enchanting significant concern and starting Islamic banking branches in their organizations, which work in compliance with the specific Islamic Shariah principles in a number of states of Pakistan. The Islamic banking structure is bizarrely facing gigantic contest by the Islamic banking sector all over the world as well as from the well-known International commercial banks that hold out services and products of IB. It is an attempt for exploration and investigation of the extensive and essential factors, which persuade consumers to choose the Islamic banking or conventional banking and the function of demographic features, which track consumers to the assortment of IB or CB in Pakistan. Sample of 341 respondents has been used in this study mainly focused on non-probability convenience test tool. Pre-institute 5 point likert survey instrument ranging from 5 to 1 was applied to gather data. The conclusion reveals that there are countless factors other than religious perception like employee and customer interactions, convenience, reputation, financial benefits \& services, and technology, which are fundamental for the consumers for the assortment of Islamic or conventional banking. The demographic characteristics of the respondents also have a significant impact. The authors expect that the crux of this study will explore new ways for the Islamic banking system to emphasis on specific emerging factors to enhance the efficiency and performance of the Islamic banking system in Pakistan. There will be enormous advantage for executives of IBs \& CBs in developing marketing approach.
\end{abstract}

Key words: Islamic banking, conventional banking, selection criteria, momentum, banking and Shariah

\section{Introduction}

In the later part of 20th century, the resurgence of Islamic ideology started its course in Muslim countries and societies. The Muslim scholars and intellectuals disputed the global imperative economic and social system and rendering the limitations. Under capitalism, interest is the major driver in conventional banks operations although other valuable services such as guarantees, funds transfers, safety of wealth, and facilitation in global trade are also provided for reward and form substantial part of income. As the conventional banks are created beneath the ideology of capitalism and transect business by indicting interest, which is offensive (banned) in Islam. This modern commercial banking system is not interest free, which is against Sharia (Islamic law), hence for all the believers in Allah (God) to deal with these institutions does not appeal. Therefore, Muslims left with no option but to set up their individual financial establishments governed by Islamic laws and principles. Islamic financial system and banking has shown an incredible growth in last two decades. By the end of December 2008, in more than 50 countries approximately 300 institutions are operational and handle funds of US\$ 951 billion. Persian Gulf Area is the centre of Islamic finance with a share of $82 \%$ followed by South Asia and Fareast region $13 \%$ and balance from all over the world including Europe, North America and Africa (IFSL 2011). So for (June 10) 06 branches of IBs and 13 CBs with Independent Islamic banking branches are operating inside Pakistan. In December 2008, Islamic financial system was operational in more than 50 countries and approximately 300 institutions were operating and they manage funds of US\$ 951 billion. Persian Gulf is the centre of Islamic finance and banking with a share of 82\% followed by South Asia and Fareast region 13\% and balance from all over the world including Europe, North America and Africa (IFSL, 2011). Pakistan has shown a tremendous growth in Islamic banking system in last six years. Number of branches has increased from 17 in 2003 to 667 within six and half years in 2009 an average annual increase of $78 \%$. Assets amplified by regular per annum rate of $76 \%$ while deposits augmented by per annum rate of $85 \%$ and financial disbursements and investments improved by per annum 
rate of $66 \%$ during the period (12/03 - 06/10). Overall an average growth of $76 \%$ per annum in the last six and half years (12/03-06/10) was achieved by Islamic banking in Pakistan.

This study is trying in the direction of understanding the mechanism of Islamic financial banking and structure compared with conventional banking. The present research is focusing to investigate popularity of Islamic Banking (IB) with business community and individuals with comparison among conventional banking (CB). For more than four decades Islamic banking system has been working like the customary banks (Qawi \& Lynn, 2001). Islamic banks also organize funds and approve advances according to Islamic laws (Shariah). These services are dissimilar from CB services or laws (Khan et al., 2007). Islamic banks structure is absolutely interest free. The structure of interest free banking has several intentions apart from this feature, like fair allocation of comfortable circumstances and improved equity sharing in the society. There is no importance of mechanism of interest within religion Islam and the Islamic banking system. The limitation concerning the prevention of "interest" (Riba) is covered in the blessed book of Quran, foundation of Islamic beliefs. It is worth mentioning here that another religion Christianity also criticize interest system in contemporary dealings (obiyo, 2008). The growing corporation worldwide has distorted aggressive outlook of the businesses in the under develop nations and accordingly entails organizational revolution to pact with modern economical prospect (Ciptono \& Soviyanti, 2007). Initial investigation of comprehensive literature and noteworthy meetings with both staff and consumers of IB; it has been publicized that IB system was started in Pakistan back in 1980. The hard work of 2 decades and 2 years were dedicated for revamping the financial sector and economy of Islamic Republic of Pakistan according to Islamic appearance but all in vain. Islamic banking system (IBs) performances have been revitalized in the Islamic Republic of Pakistan (IRP) according to the duel banking system in 2002 though. In the meantime, 06 entirely committed IBs functioning their operations and which are managing their operations all the way through 52 branch offices instituted 16 main cities of Islamic Republic of Pakistan crosswise. They consist of Bank Islami, Al Baraka Islamic bank, Meezan Bank, First Dawood Islamic bank, Emirates Global Islamic bank, and Dubai Islamic Bank Pakistan. Akhtar (2006) described that there are almost nine national and International banking organizations that have also selling IB services and products that make 62 exclusively dedicated Islamic banking branches throughout Pakistan.

This concludes that IBs are facing excessive contest, as CBs are also started offering IB counters (Haque \& Osman et al, 2009). Hence, it is extremely imperative for IB participants to enhance and develop Islamic banking sector to compete in the market. Consumer prefer to handle its dealings by IB due to religious factor it is not true. It is also examined that IB services and products will not be prominent to commercial consumers except their overheads are lesser than the services and products of the CBs (Sudinharon \& Ahmed, 2001). Likewise, Osman et al. (2009) confirmed that to be competent in the banking industry Islamic banks must have to proffer valuable services, products and competencies to contend with conventional banks instead of just compromise at Islamic emergence, appearance and image. These facts are the attractive factors, which compel to consider the important factors, which convince consumers to compact with Islamic banks. Taking account an extensive literature review; it has been noticed that no study is available to find out the important prospective factors, which influence customers to deal with Islamic banking services and products. Thus, it will be an involvement to entire people of Pakistan especially within area of Islamic banking. In addition, this research is the expansion of results of a previous study, which only took the sample of the college students (Almossawi, 2001). On the other hand, the current study tries to find out to employ significant demographic features with the help of earlier literature. Additionally, the present study explored the impact of religion perspective while selecting a bank by individual customer for its transactions. As well, (Almossawi, 2001) observed the assortment criterion of consumers in commercial banks while this research examined in the perception of both banking systems with more focus on Islamic banks and see how its effects the selection criterion in Islamic civilization approaching Pakistan. The study is determined to answer a question whether Islamic banking is becoming popular among businesses and individuals because of religion or due to its repute and benefits offered to customers and clients. 


\section{Literature Review}

Various investigations have explored the most important motivations which be capable of encourage the customers to pact through Islamic banking (IB) instead of just taking only Conventional banking (CB) option in different geographical areas in different time frameworks. Metwally and Jalaluddin (1999) elucidated that religious convictions are not the factors that inspires SME's in Australia to employ income and loss contribution approaches of finance. Likewise, Naser et al. (1999) instituted that majority very significant issues influencing approach heading for Islamic banks were repute rather than the religion. Nordin and Hamid (2001) verified about respondents that mainstream in Malaysia recognize the reality of Islamic banking. Roughly 50 percent of the respondent's pact with Islamic bank however other percentage of the respondents cannot distinguish among the services and products offered by conventional and Islamic banks. Haron \& Ahmad (2002) investigated that the majority of the respondents specify that economic conditions and religion were important factors for selecting banking services. Even though nearly everyone of the respondents were non-Muslims, but sensitive concerning Islamic banking as an option to commercial banking and 75 percent of respondents settled that IB in Malaysia require to encourage their services and stuff in an improved way. Mainstream consumers of Islamic banking were contented through services and products of IBs \& the majority had advanced altitude of understanding regarding Islamic financial procedures and utilizing finance. Similarly, Al-Sultan (1999) argued that even though 52 percent of customers of Islamic banking desire to deal with commercial banks due to better services and products, however, yet observance to religion of Islam are foremost inspiration for commencing Islamic banking. Almossawi, (2001) demonstrates the bank assortment criterion employed by the college undergraduates in Bahrain. The result exposed that major factors formative undergraduates bank selection were;friendly personnel, bank repute, location and accessibility of ATMs, availability of parking service. Additionally, the gender mottled in the banking assortment criterion. Sudinharon and Ahmed, (2001) considered the observation of business consumers towards islamic banking in malaysia and instituted that the majority significant factor supposed by commercial consumers is the fee of the services and products in selecting banks . It assumes that Islamic banking services motivation will not be striking to mutual consumers except outlays are lesser than the services, products and competencies of the commercial banking.

Later on, Okumus (2005) acknowledged that the mainstream of the respondents matured that most important basis for the employment of Islamic banking services was religion. The majority of the consumers were mindful of fundamental Islamic approach of services and products, but not aware of superior Islamic banking system. Dusuki \& Abdullah, (2007) observed that the most imperative concerns that persuade consumers to compact with Islamic banking principally in a double banking structure. The outcome exposed that the assortment of IBs materializes to be primarily mixture of excellence services available and both repute of Islamic form of financing and the Islamic banking itself. Enduring issues alleged to be significant comprise of convenience, product price, and good social responsibility practices. Likewise, Worthington and Gait, (2008) examined the awareness of services and products of IB, sensitivity, and attitudes. The outcome publicized that though religious firmness is an important factor in the employment of IBs, clients also categorize bank pricing strategy, reputation, and service quality as significant. Ismail et al (2009) explained most important factors by employing Logit model that persuade consumer awareness in Islamic banking. The study recognized that there was considerable positive correlation of religious and social perspective, availability of services, and trust on bank with observation of consumer in relation to Islamic banking. However, Cater model is employed by Osman et al (2009) to look at the association of customer satisfaction and service quality in Bangladesh. It concludes that Islamic banking approach has to offer quality services and products to remain competitive instead of compromising on Islamic appearance and emergence. A previous study on Jordanian consumers in which the researchers examined the approach of Jordanian community towards interest frees Islamic banking. In the end, they found that the most important cause for the assortment of financial establishment is not religion; nevertheless, several additional issues too are manipulating the assessment criterion of consumers and with this connection, main issue is the intensity of return, i.e., profit on investment (El-Bdour and Erol, 1989). Another study was conducted on Malaysian consumers and confirmed the many other important factors that customers well thought-out in selecting the financial institution (Sudin et al, 1994). The results showed in the study of Metwally (2002) those women, the 
elderly and people's civil servants to give priority to income and middle-level education is relatively lower than the traditional banks and Islamic banks.

FIGURE 1: THEORETICAL FRAMEWORK (MODEL FOR THE STUDY)

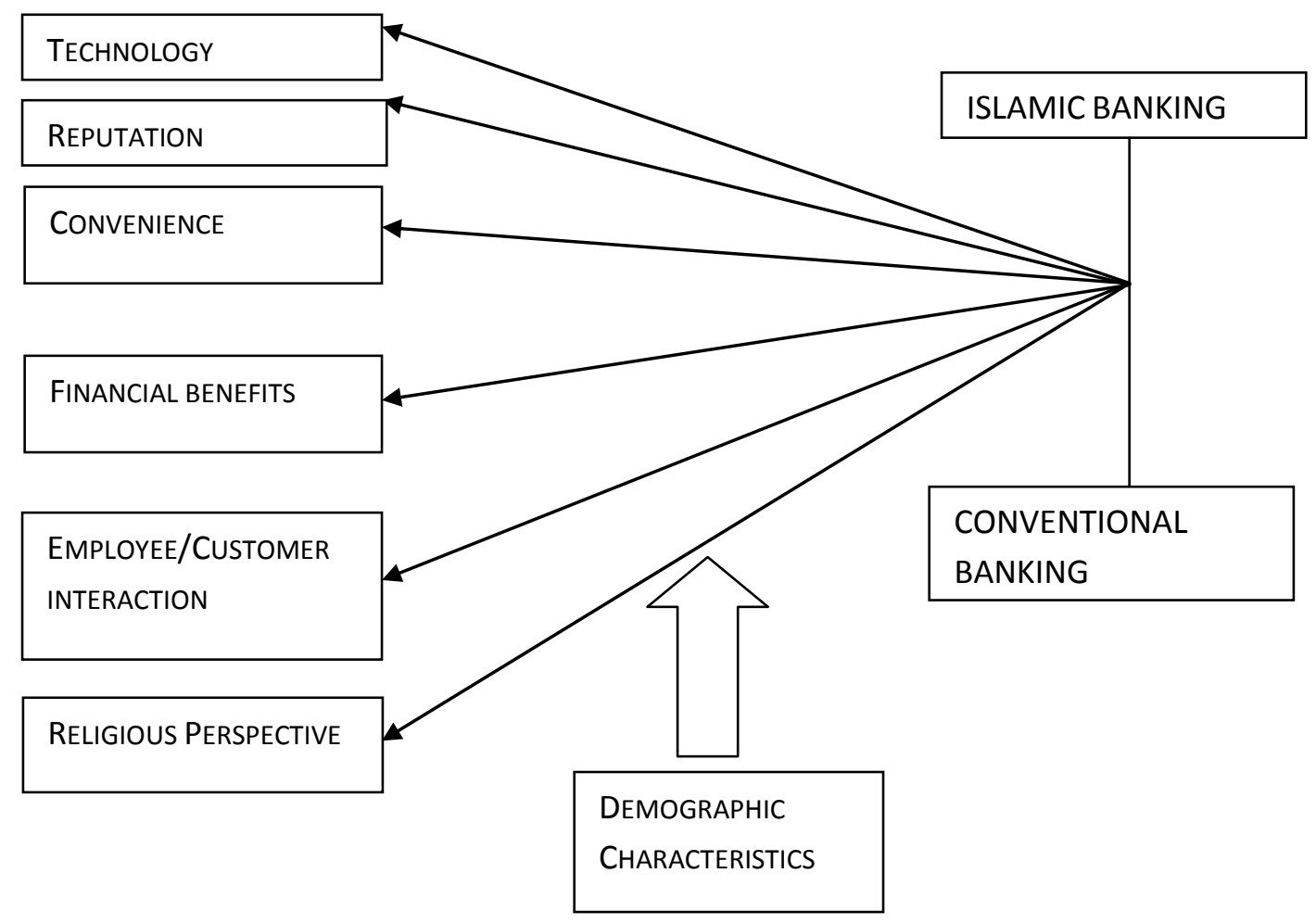

The Study Research Issues: The study collects the information regarding perceptions of Islamic banking customers about their preference of Islamic banking and important issues and factors playing role in their decision to depart conventional banking in Pakistan and choose Islamic banking. The issues engaged into research comprise technology, convenience, benefits and services, employee-customer interaction and religious issues. The study investigates the important factors influencing customers toward Islamic banking. It highlights the role of religious factor among other important factors in promoting the culture of Islamic banking. The study develops an estimate of perception of customers of IB in Pakistan and generalizing results over the populace of under develop Muslim countries. The study attempts to concentrate on the subsequent questions:

- What is the understanding level of customers about Islamic banks?

- Why customers in Pakistan preferring Islamic banking instead of conventional banking?

- What are the overall perceptions of customers about Islamic banking?

- Is there any role Islamic banking can play to promote Islamic culture in the society?

- What are the important factors, which motivate customers to switch towards Islamic banking?

\section{Methodology}

Sample: The study collected data from customers regarding the perceptions of Islamic banks about their preferences of Islamic banking and important issues and factors taking part in their decision to depart conventional banking in Pakistan and adopt Islamic banking. The issues included in the study were technology issues, reputation issues, convenience issues, benefits and services issues, employee-customer interaction issues and religious issues. In this study, we employed non-probability convenience sampling technique, as a substitute of a probability sampling. Furthermore, this approach was employed for data 
anthology process because of cost constraints. The sample size for this study was 341 banking customers consisting of 228 male and 113 female. Questionnaires were distributed directly to all the respondents of six Islamic banks in three cities of Pakistan namely Islamabad, Rawalpindi and Gujranwala by the researcher himself. The respondents included in the sample were from the diverse category of income and social class. Each of the respondents was screened out properly to avoid any error, incomplete or missing responses. 400 questionnaires were distributed and utilizable questionnaires were 341 , hence the response rate of this study was $85 \%$, which considered encouraging. With the purpose of study the uniformity and reliability of scale, Reliability analysis was computed for every dimension included in the whole instrument.

Measures: The study adopted the questionnaire and shaped in the light of bank selection criteria used and tested in Bahrain Almossawi, (2001). The questionnaire was organized in six sections. The first section described the demographic profile of the respondents (gender, age, education, occupation, monthly income etc). Second section was regarding the information related to technology employed by Islamic banks or conventional banks for customers (Fast \& Efficient counter services, Speed and Efficiency of Transaction, 24 Hours ATM services, e banking) \& reputation. Section three of the questionnaire as about convenience factor (Convenience ATM locations, Pleasant bank atmosphere, and no. of branches). Section four was organized to collect data about benefits and services Islamic banks offered to its customers (ATM Debit card with free annual charges, little service charge, Ease of obtaining finance, Ease of opening current account). The fifth section revealed the information regarding customer/employee interaction (Affability of bank employees, Attractive response from the bank employees, experienced management team). The sixth and final section contributed to find out the religious perspective and its influence on customers to move towards Islamic banking (Provision of Interest free loans, Provision of Islamic product and services, conducting business on Islamic law \& principles). In the survey, the respondents were enquired to indicate the degree of agreement on a five point Likert scale, with collection of 'strongly agree' to 'strongly disagree', contained 27 attributes with five dimensions.

Procedure: Most of the surveyed questionnaires were delivered in person amongst respondents. Prior to distribution of the questionnaires, terse prelude in relation to the research idea was given to the respondents so that the study achieved only relevant data. The questionnaires were filled up by the consumers of IBs and CBs, which were directly distributed to the customers of six Islamic banks in three cities of Pakistan (banks names and cities names are mentioned above). The banks i.e., Dubai Islamic , Meezan, Muslim commercial, Al Baraka Islamic, Habib bank Ltd, Bank Islami, First dawood Islamic, and United Bank were visited in three cities of Pakistan. The assessment information was attained once. SPSS (statistical package for social sciences) was used to analyse the information. With the purpose of study the reliability and uniformity, reliability analysis was computed of every dimension included in the whole instrument. Pilot study testing was done to validate the scale.

\section{Results \& Discussion}

Consumer's assortment criterion for IB or CB in Pakistan reveals several common features and resemblance. The technology dimension has main attraction with Islamic law \& principles for consumers interested especially in only IB among other features. The investigation analyzes the observation of 341 consumers of CB and IB in connection with their assortment criteria and preferences. Descriptive statistics is applied to gather the demographic data analysis. Consumer's summary is one of the segments in the survey. A summary of respondents in connection with all demographics and targeted banks is exposed in Table 1. Table 1 reveals that the gender percentage of respondents is 66.9 percent (males) and 32 percent (females). Immense group were young respondents from mature age 26-32, pursued by very young age groups 18-25. Additionally, about half of the respondents shared that they possess bachelor's degree 49.3 percent and more than quarter of the respondents have master's degree 26.1 percent. Furthermore, about half of the respondents are working people 49.3 percent, followed by 37.8 percent respondents were running their own businesses and only 7 percent respondents were studying, 5.9 percent are associated with other occupations. In relation with monthly income, 44.6 percent approx. half of the respondents were earning 15000-50000 per month, 24.6 percent quarter of the respondents is earning less than 15000, 19.1 percent respondents earning 50000100000 and (11.7-\%) respondents earning capacity is 1000000 -Above. 
The mean score and ranks of all the factors are shown in Table 2.The results reveal that for Islamic banks customers, the five most influential factors for Islamic bank selection are:

- Transparency in transactions

- Run on Islamic law \& principles

- Ethical behaviour of employees

- Low service charges

- Speed \& efficiency of transaction

Table 1: Demographic summary in connection with targeted banks $N=341$

\begin{tabular}{lcccc}
\hline Descriptions & Frequency & Percentage & Valid (\%) & Cumulative (\%) \\
\hline Bank: & & & & \\
Islamic Banks & 202 & 57.7 & 59.2 & 59.2 \\
Conventional Banks & 139 & 39.7 & 40.8 & 100 \\
Gender: & & & & \\
Male & 228 & 66.9 & 66.9 & 66.9 \\
Female & 109 & 32 & 32 & 98.8 \\
Age: & & & & 31.7 \\
18-25 & 108 & 31.7 & 31.7 & 70.7 \\
26-32 & 133 & 39 & 39 & 91.8 \\
33-39 & 72 & 21.1 & 21.1 & 100 \\
40-Above & 28 & 8.2 & 8.2 & 5.9 \\
Education: & & & & 24.6 \\
Matric & 20 & 5.9 & 5.9 & 73.9 \\
Intermediate & 64 & 18.8 & 18.8 & \\
Bachelors & 168 & 49.3 & 49.3 & 7 \\
Masters & 89 & 26.1 & 26.1 & 44.9 \\
Occupation: & & & & 94.1 \\
Student & 24 & 7 & 7 & 100 \\
Businessman & 129 & 37.8 & 37.8 & 24.6 \\
Employee & 168 & 49.3 & 49.3 & 69.2 \\
Other & 20 & 5.9 & 5.9 & 100 \\
Monthly Income: & & & & \\
Less than 15000 & 84 & 24.6 & 24.6 & \\
15000-50000 & 152 & 44.6 & 44.6 & 19.1 \\
50000-100000 & 65 & 19.1 & 11.7 & \\
1000000-Above & 40 & 11.7 & & \\
\hline
\end{tabular}

Table 2 renders that the customers who are aware of Islamic banking and have good understanding of it, most of them like transparency in transaction factor (4.16.02) that Islamic banking can bring positive change in the banking culture, encourages transparency in business operations, is applicable in Pakistan and is supportive in now establishing the business sector and in general the country's economy. A lesser mean (4.1070) agrees that Islamic law and principles factor also contributing as significant addition to attract customers ethically. All variables in this study are standardized to a five-point likert scale, with five as the lowest or weakest value and one as the strongest agreement or highest value. In the present study, the Table3 shows that mean for technology is greater $(20.6691>20.4010)$ in conventional banking with competing Islamic banking. Table- 3 shows that technology has higher scores on conventional banking and, therefore, bank customers are more influenced by conventional banking in technology. The study reveals through Table-3 that mean for reputation motive between conventional and Islamic banking is greater in conventional banking $(20.6691>20.4010)$. Table-3 confirms that conventional banking has higher scores than Islamic banking on reputation and, therefore, conventional banking are more influenced and motivated to go for 
unusual goals. The study demonstrates in Table-3 that mean for convenience between conventional banking and Islamic banking is greater in conventional banking (28.331 > 27.7327).

Table 2: Perception of Customers towards Islamic banking with ranking importance of bank selection criteria factors among potential customers $\mathrm{N}=341$

\begin{tabular}{|c|c|c|}
\hline Factors & Mean & Rank \\
\hline Transparency in transactions & 4.4956 & 1 \\
\hline Run on Islamic law \& principles & 4.3812 & 2 \\
\hline Ethical behaviour of employees & 4.3314 & 3 \\
\hline Low service charges & 4.2933 & 4 \\
\hline Speed \& Efficiency of transaction & 4.2757 & 5 \\
\hline 24 Hors ATM services & 4.2493 & 6 \\
\hline Convenience ATM locations & 4.2141 & 7 \\
\hline Provision of Interest free loans & 4.2023 & 8 \\
\hline Bank Reputation & 4.1760 & 9 \\
\hline Ease of opening current account & 4.1701 & 10 \\
\hline ATM debit card with no annual fees & 4.1691 & 11 \\
\hline Pleasant bank atmosphere & 4.1642 & 12 \\
\hline Fast \& Efficient Counter Services & 4.1554 & 13 \\
\hline Experienced management team & 4.1290 & 14 \\
\hline Friendliness of bank personnel & 4.1056 & 15 \\
\hline Convenient bank location & 4.0616 & 16 \\
\hline Several branches & 4.0469 & 17 \\
\hline Ease of obtaining finance & 3.9795 & 18 \\
\hline Provision of Islamic products \& services & 3.9589 & 19 \\
\hline Provision of profit sharing investment products & 3.8739 & 20 \\
\hline Reception at the bank & 3.8416 & 21 \\
\hline Home banking/Internet banking & 3.6540 & 22 \\
\hline Recommendation of relatives & 3.3490 & 23 \\
\hline Friday Banking & 3.3372 & 24 \\
\hline Recommendation of friends & 3.3021 & 25 \\
\hline
\end{tabular}

Table 3: Group Statistics

\begin{tabular}{|c|c|c|c|c|c|}
\hline Bank & & $\mathbf{N}$ & Mean & Std. Deviation & Std. Error Mean \\
\hline \multirow[t]{2}{*}{$\mathrm{T}$} & Islamic banking & 202 & 20.4010 & 3.41676 & .24040 \\
\hline & $\begin{array}{l}\text { Conventional } \\
\text { banking }\end{array}$ & 139 & 20.6691 & 3.28675 & .27878 \\
\hline \multirow[t]{2}{*}{$\mathrm{RP}$} & Islamic banking & 202 & 20.4010 & 3.41676 & .24040 \\
\hline & $\begin{array}{l}\text { Conventional } \\
\text { banking }\end{array}$ & 139 & 20.6691 & 3.28675 & .27878 \\
\hline \multirow[t]{2}{*}{$\mathrm{C}$} & Islamic banking & 202 & 27.7327 & 4.01215 & .28229 \\
\hline & $\begin{array}{l}\text { Conventional } \\
\text { banking }\end{array}$ & 139 & 28.3381 & 3.61870 & .30693 \\
\hline \multirow[t]{2}{*}{ BS } & Islamic banking & 200 & 16.6200 & 2.99507 & .21178 \\
\hline & $\begin{array}{l}\text { Conventional } \\
\text { banking }\end{array}$ & 137 & 16.6715 & 2.88533 & .24651 \\
\hline \multirow[t]{2}{*}{ INT } & Islamic banking & 202 & 12.2129 & 2.13924 & .15052 \\
\hline & $\begin{array}{l}\text { Conventional } \\
\text { banking }\end{array}$ & 139 & 11.8777 & 2.20165 & .18674 \\
\hline \multirow[t]{2}{*}{$\mathrm{R}$} & Islamic banking & 202 & 32.0693 & 4.76776 & .33546 \\
\hline & $\begin{array}{l}\text { Conventional } \\
\text { banking }\end{array}$ & 139 & 31.6403 & 4.88121 & .41402 \\
\hline
\end{tabular}


The study explores that conventional banking has higher scores than Islamic banking on convenience and, therefore, conventional banks are more willing to take risk and accept challenges. The present study explains in Table-4 that mean for benefits and services motive between conventional banking and Islamic banking is greater in conventional banking $(16.6715>16.6200)$. The study further confirms in Table- 3 that benefits and services have higher scores on conventional banking than Islamic banking and, therefore, conventional banks are more ready to deal uncertain and challenging situations. The study indicates in Table-4 that mean for customer/employee interaction motive between conventional and Islamic banking is greater in Islamic banking (12.2129 > 11.8777).The study further explains in Table-3 that Islamic banking has high scores than conventional banking on customer/employee interaction and, therefore, Islamic banking is more inclined to maintain the status quo. The study indicates in Table-3 that mean for religious perspective motive between conventional and Islamic banking is greater in Islamic banking $(32.0693>31.6403)$. The study further explains in Table-3 that Islamic banking has high scores than conventional banking on religious perspective and, therefore, Islamic banking is more influenced for religious perspective.

Discussion: In the present study all six variables; technology issues, reputation issues, convenience issues, benefits and services issues, employee-customer interaction issues and religious issues have been compared with one another for achieving targeted motives. In present study, the first issue understanding level of customers about Islamic banking system was confirmed. Table 1 reveals that about half of the respondents shared that they possess bachelor's degree 49.3 percent and more than quarter of the respondents have master's degree 26.1 percent. Furthermore, about half of the respondents are working people 49.3 percent, followed by 37.8 percent respondents were running their own businesses and only 7 percent respondents were studying, 5.9 percent are associated with other occupations. Mostly literate people connected with Islamic banking system due to their high understanding with Islamic banking system. In this study, the second issue preference of Islamic banking system in Pakistan was confirmed. As the conventional banks are created beneath the ideology of capitalism and transect business by indicting interest, which is offensive (banned) in Islam. This modern commercial banking system is not interest free, which is against Sharia (Islamic law), hence for all the believers in Allah (God) to deal with these institutions does not appeal. Therefore, Muslims left with no option but to set up their individual financial establishments governed by Islamic laws and principles. In this study, the third issue the overall perception of customers about Islamic banking system was confirmed. It assumes that Islamic banking services motivation will not be striking to mutual consumers except outlays are lesser than the services, products and competencies of the commercial banking. Sudinharon and Ahmed, (2001) considered the observation of business consumers towards islamic banking in malaysia and instituted that the majority significant factor supposed by commercial consumers is the fee of the services and products in selecting banks.

\section{Conclusion}

The prime intention of conducting this research was to highlight the factors which groups of consumers prefer to select while transact with bank in Pakistan with comparison of IB and CB. The research is not only dissimilar with prior studies although give the significant evidence to successful approach development. In the globe, we find that there are several trends emerging, which have enhanced the importance of Islamic banking in all over the world and people, are taking interest in Islamic banking due to religious and friendliness of Islamic banks employees. Even modern conventional banks are also selling Islamic banks products for seeking profit due to consumer demand and an option engender to not to rely on commercial banks only. This research is performed to gather information concerning the consumers to choose IB or other commercial banks and comparing the mechanism of IB and conventional banking in consumer perspective. Our study reveals that consumers in Pakistan prefer first their comfort and ease to transact with IB or CB. Religious perspective is important but only dependability of religious perception cannot executed the needs of the consumers. Several examined factors play their role to inspire the consumers to attract toward IB or CB such as financial benefits, services, convenience factor, employee/customer interaction and technology. It means both banking system consumers would not stay or continue to transact with banks unless both system do not offer indispensable and necessary services and benefits according to their demands. 
Practical/Managerial Implication: Consecutively, to make sure flourishing advancement, Islamic banks can be optimally managed in stipulations of above shown results. An aim programming practice to attain such a most advantageous policy is depicted and their features are presented in this study. These characteristics clearly transmit strong implications for all management of Islamic banks. Consumer sensitivity can be interceded the special effects of bank service quality on performance. Consumer opinion and contentment can be well thought-out as the main difference to bank for in general performance. Nuradli and Hanifah, 2008 investigated that if Islamic banks ignore the service quality issue than it might be possible that the conventional banks shall be benefited. The significance of this study can be analyzed from two magnitudes: hypothetical contributions and realistic implications. Hypothetically, the study covers an essential break in the literature with the purpose of investigate bank preference criterion for prospective consumers in the Pakistan. On the realistic part, this study can assist bank players to categorize the major issue that may establish bank assortment assessment among Pakistani Islamic banking consumers. This study should help the management of Islamic banks in work out suitable marketing plans for attainment and magnetize Islamic banking customers in Pakistan.

Future Research: The research can also collect the perception of managers, employees and senior staff and overall management about the role of Islamic banks in developing the consumer satisfaction culture in the Pakistan. This study supposes that morally and in a social context responsible management can customize and execute Islamic banking development in the Pakistani Islamic banking sector.

\section{References}

Abdul-Qawi, O. \& Lynn, O. (2001). Adopting and measuring customer service quality in Islamic banks: A case study in Kuwait Finance. House. Int. J. Islamic finance Service, 3, 1-26.

Ahmed, N. \& Haron, S. (2002). perception of malysian corporate customers towards islamic banking product and services. International journal of islamic financial services , 03 (04),13-29.

Ahmed, N. \& sudinharon, F. (2001). Perceptions of malaysian corporate customers towards Islamic banking products and services. International Journal of Islamic Financial Services , 03 (04).

Akhtar, S. (2006). The financial sector of Pakistan-the road map. Islamic finance news , 03 (16), 11-12.

Almossawi, M. (2001). Bank selection criteria employed by college students in Bahrain: An empirical analysis. Intenational journal of bank marketing , 19(03), 115-125.

Al-sultan, W. (1999). Financial chracteristics of interest free banks and conventional banks. PHD dissertation University of wollongong .

Ciptono, W. \& Soviyanti, E. (2007). Adopting islamic banks' CATER model: An empirical study in RIAU'S Syariah banks, Indonesia. Proceeding PESAT Auditorium Kampus Gunadarma , 02, 1858-2559.

Dusuki, A. W. \& Abdullah, N. I. (2007). Why do Malaysian customers patronise Islamic banks? international journal of bank marketing , 25 (03),142-160.

Erol, C. \& El-Bdour, R. (1989). Attitudes, behavior, and patronage factors of bank customers towards Islamic banks. International Banking \& Marketing, 7(6), 31-37.

Gait, A. \& Worthington, A. (2008). An empirical survey of individual consumer, business firm and financial institution attitudes towards Islamic methods of finance. International Journal of Social Economics, 35 (11), 783-808.

Hamid, A. \& Nordin, N. (2001). A study of islamic banking education and strategy for the new millenniumMalysian experience. International journal of islamic financial services , 02(04), 3-11.

Haque, A., Osman, J. \& Ismail, A. (2009). Factor Influences Selection of Islamic Banking: A Study on Malaysian Customer Preferences. American Journal of Applied Sciences , 06 (05), 922-928.

Haron, S., Ahmed, N. \& Planisek, S. (1992). Requirement and selection decisionof customers in islamic and conventional banking environment. Malaysian management journal , 01 (01), 25-33.

IFSL. (2011). International Financial Services Limited Research on Islamic Finance report. http://www.ifsl.org.uk/output/ReportItem.aspx?NewsID=32 (accessed on July 07, 2011).

Jalaludin, A. \& Metwally, M. (1999). profit/loss an alternative method of financing small business in Australia. The middle East Business and economic review , 11(01), 8-14.

Khan, M., Hassan, M. \& Shahid, A. (2007). Banking Behavior of Islamic Bank Customers in Bangladesh. Journal of Islamic Economics, Banking and Finance, 2, 160-194. 
Metwally, M. (2002). The impact of demographic factors on consumer selection of a particular bank within a dual banking system-A case study. Journal of international marketing and marketing research, 27 (01),35-44.

Naser, K., Jamal, A. \& Al-Khatib, K. (1999). Islamic banking: A study of customer satisfaction and prefrences in jordan. International journal of bank marketing, 17(03),135- 150.

Nuradli, R. S., Hanifah, A. H., Shahida, S. \& Hairunnizam, W. (2008). Factors Influencing the Islamic credit cards holder's satisfaction. The business review, Cambridge, 11(2), 1-8.

Obiyo, 0. (2008). Islamic financing/banking in the Nigerian economy Is it workable? A review of related issues and prospects. International Journal of Islamic and Middle Eastern Finance and Management, $01(03), 227-234$.

Okumus, H. (2005). Interest free banking in Turkey: A study of customer satisfaction and Bank selection criteria. Journal of economic corporation, 26 (04), 51-86.

Osman, I., Ali, H., Zainuddin, A., Rashid, W. \& Jusoff, K. (2009). Customers Satisfaction in Malaysian Islamic Banking. International Journal of Economics and Finance, 01(01), 197-202.

Shah, N. \& Hamid, H. (2008). Comparing the Islamic Banking, Conventional and both banking users using multinomial logistic regression.International accounting and business conference, 2008.

Sudin, H., Norafifah, A. \& Sandra, L. P. (1994). Bank Patronage Factors of Muslims and NonMuslim Customers. International Journal of Bank Marketing, 12(01), 32-40. 